\title{
CCURRENCE OF AQUATIC MACROINVERTEBRATES IN AN EXTRATIVIST RESERVE OF BRAZILIAN AMAZON
}

\author{
Diego Ferreira Gomes \\ Universidade Federal do Rio de Janeiro, Programa de Pós-Graduação em Ciências Bioló- \\ gicas (Biofísica), Cidade Universitária, Ilha do Fundão, 21941-902, Rio de Janeiro, Bra- \\ sil, diego.frgomes@gmail.com.
}

\begin{abstract}
Nathalie Aparecida de Oliveira Sanches
Universidade de Araraquara - UNIARA, Programa de Pós-Graduação em Desenvolvimento Territorial e Meio Ambiente, Araraquara, São Paulo, Brasil, nathalie.sanches3005@gmail.com.
\end{abstract}

\section{Douglas de Pádua Andrade}

Universidade Federal de São Carlos, Departamento de Ecologia e Biologia Evolutiva, São Carlos, São Paulo, Brasil, douglas.p.andrade@gmail.com.

\section{Wanderley Rodrigues Bastos}

Universidade Federal de Rondônia, Porto Velho, Rondônia, Brasil, wanderleybastos@yahoo.com.br.

\begin{abstract}
Freshwater invertebrates occupy important roles in ecological processes and are frequently used as indicators of water quality. Their existence, however, is still obscure in many regions of the country, i.e. very few relevant studies have been conducted regarding their presence especially in the Amazon region. Thus, this study aimed to present an inventory of aquatic macroinvertebrates from the marginal region of an Amazonian lake. This study was conducted in a floodplain area, at the Extractivist Reserve of Cuniã Lake (margin of the Madeira River). To sample macrofauna were collected sediment and aquatic macrophytes near the marginal region in seven sites during the lowwater season (August 2015) and the high-water season (February 2016). The environmental variables (water temperature, electric conductivity, $\mathrm{pH}$, and dissolved oxygen were measured at each site and concentrations of organic matter in the sediment were also determined. A total of 28 taxa were recorded. The most significant taxa for the lake were the genera: Campsurus (Ephemeroptera: Polymitarcydae) and Tenagobia (Hemiptera: Corixidae). The lake presents diverse macrofauna, indicating good environmental quality and organic enrichment, which highlights the importance of flood in the composition of local macrofauna.
\end{abstract}

Keywords: floodplain area, Madeira river, western Amazon.

\section{OCORRÊNCIA DE MACROINVERTEBRADOS AQUÁTICOS EM UMA RESERVA EXTRATIVISTA DA AMAZÔNIA BRASILEIRA}

Resumo: A fauna de invertebrados aquáticos possui um papel relevante nos diversos processos ecológicos e são frequentemente utilizados como indicadores de qualidade da água, porém ainda é pouca conhecida em diversas regiões do país, especialmente na região amazônica. Assim, este estudo teve como objetivo apresentar um inventário de macroinvertebrados aquáticos da região marginal de um lago amazônico. Este estudo foi realizado em uma área de inundação, na Reserva Extrativista do Lago Cuniã (margem do rio Madeira). Para a amostragem da macrofauna, foram coletados sedimentos e macrófitas aquáticas próximas à região marginal em sete locais, durante a estação de Águas baixas (Agosto de 2015) e Águas altas (Fevereiro de 2016). As variáveis ambientais (temperatura da água, condutividade elétrica, $\mathrm{pH}$ e oxigênio dissolvido foram medidas em cada ponto e as concentrações de matéria orgânica no sedimento também foram determinadas. Foram registrados um total de 1009 macroinvertebrados, distribuídos em 28 táxons. Os táxons mais significantes para o lago foram os gêneros Campsurus (Ephemeroptera: Polymitarcydae) e Tenagobia (Hemiptera: Corixidae). O Lago estudado apresentou uma macrofauna diversa, tanto táxons indicadores de boa qualidade ambiental, como táxons indicadores de enriquecimento orgânico, enfatizando a influência da inundação na composição da fauna.

Palavras-chave: área de inundação, rio Madeira, Amazônia ocidental. 


\section{INTRODUCTION}

The Amazon basin covers about 700,000 $\mathrm{km}^{2}$ (Hamada et al., 2014), and is formed by extensive rivers, streams, lakes and floodplains, forming one of the largest water systems in the world, which serves as a cradle for countless species (Aprile \& Darwich, 2013). The main characteristic of Amazon region is the periodic change in the volume and chemical composition of its water, due to seasonal action of the flood cycle (Junk, 1997). This phenomenon changes the structure of the landscape and the biological communities that inhabit it (Monteiro et al., 2015).

Despite the growing scientific effort to study this biome, the aquatic systems of the Amazon are still underexploited and mostly unknown, mainly due to its large territorial extension and difficult-to-access sites (Hamada et al., 2014). However, it is important to know the ecology and richness of neotropical species to fill gaps in global biodiversity data (Hortal, 2015). To aggravate this scenario, small animals, such as invertebrates, without conservationist appeal and without direct relation to current economic activities, end up being neglected in studies of ecology and species diversity (Magurran, 2011).

In this sense, the invertebrate fauna of freshwater environments, despite having a relevant role in the many ecological processes, is still mostly unknown in several regions of the country, especially in the Amazon (Hamada et al., 2014; Gomes et al., 2017). This group of animals is very diverse, both in species and in adaptations, and their occurrence and distribution are related to several environmental factors of aquatic systems, of which we can highlight: availability of dissolved oxygen, availability and quality of food resources, type of sediment, type of substrate, temperature and the biotic community relationships (Wetzel, 2001; Esteves, 2011; Hamada et al., 2014).

Notably, animals of the aquatic macrofauna can colonize the most varied types of aquatic habitats, living in water columns, sediment, roots, decomposing leaves and in association with other organisms (Merritt \& Cummnis, 1996). Thus, these organisms are often used as indicators of water quality and may reveal changes in water systems caused by natural phenomenon or by anthropogenic actions (Uherek \& Gouveia, 2014).

Furthermore, physical and chemical characteristics, biomass and seasonal duration of vegetation can directly influence the composition and abundance of aquatic macroinvertebrates in these environments (Van Den Berg et al.,1997). In Amazon, this relationship has already been evidenced by researchers, such as Nessimian et al. (1998); Callisto \& Esteves (1998); Lopes et al. (2011); Hamada et al. (2014) and Uherek \&
Gouveia (2014). Thus, due to the ecological importance of this group, this research aims to present an inventory of aquatic macroinvertebratess of the marginal region of an Amazonian lake and analyze the relationship between aquatic macroinvertebrates and environmental variables highlighting mainly the changes between the seasons of lowwaters and high-waters.

\section{Materials and Methods}

\section{STUDY AREA}

This study was conducted in a floodplain area, at the Extractivist Reserve of Cuniã Lake (margin of the Madeira River) near the capital of Porto Velho-Rondônia (Fig. 1). The reserve has an area of approximately 55,850 hectares, with high diversity of fauna, flora and habitats. The lake region is seasonally flooded by the waters during the rainy season receiving great influence of the Madeira River, which in changes some parameters, but without causing environmental damage and these waters are characterized by the high concentration of dissolved and suspended organic matter (Junk, 1997). The reserve has approximately 350 inhabitants that are distributed around the lake.

\section{SAMPLING}

To sample macrofauna, were collected near the marginal region in seven sites during low-water season (August 2015) and the highwater season (February 2016): S1 (08 $20^{\prime}$ $\left.15.5^{\prime \prime S ~} 63^{\circ} 31^{\prime} 38.5^{\prime \prime} \mathrm{W}\right), \mathrm{S} 2\left(08^{\circ} 20^{\prime} 08.9^{\prime \prime} \mathrm{S} 63^{\circ}\right.$ $\left.31^{\prime} 04.8^{\prime \prime W}\right), \mathrm{S} 3\left(08^{\circ} 19^{\prime} 44.3^{\prime \prime S} 63^{\circ} 31^{\prime} 23.4^{\prime \prime W}\right)$, S4 $\left(08^{\circ} 19^{\prime} 37,3^{\prime \prime} \mathrm{S} 63^{\circ} 30^{\prime} 29.2^{\prime \prime W}\right)$, S5 (08 $19^{\circ}$ $\left.10.9^{\prime \prime} \mathrm{S} 63^{\circ} 30^{\prime} 01.9^{\prime \prime} \mathrm{W}\right), \mathrm{S} 6\left(08^{\circ} 19^{\prime} 22.8^{\prime \prime} \mathrm{S} 63^{\circ}\right.$ $\left.29^{\prime} 29.5^{\prime \prime} \mathrm{W}\right)$, and S7 (08 $18^{\prime} 40.0^{\prime \prime S} 63^{\circ} 29^{\prime}$ 19.0"W) (Fig. 1). These sites were chosen to cover the entire length of the lake and because they are in places of lower depth and easier access. Three samples were collected at each site and in each season (low waters and high waters), totaling 42 samples.

The sampling procedure was based on the use of a "D" net-sampling (mesh size of $0.25 \mathrm{~mm}$ ) by scanning method of approximately 2 meters with a sampling effort of one minute. Sampling of the superficial sediment collected with the net, also brought much vegetal material provenience of macrophytes and the surrounding trees. The samples were stored in plastic containers and oxygenated with aquarium pumps (Boyu Air Pump SC3500) to keep organisms alive during the screening process. The selected organisms were fixed and preserved in alcohol at $70 \%$ (Alves \& Gorni, 2007). Taxonomic criteria adopted by Hamada et al. (2014); Merrittt \& 


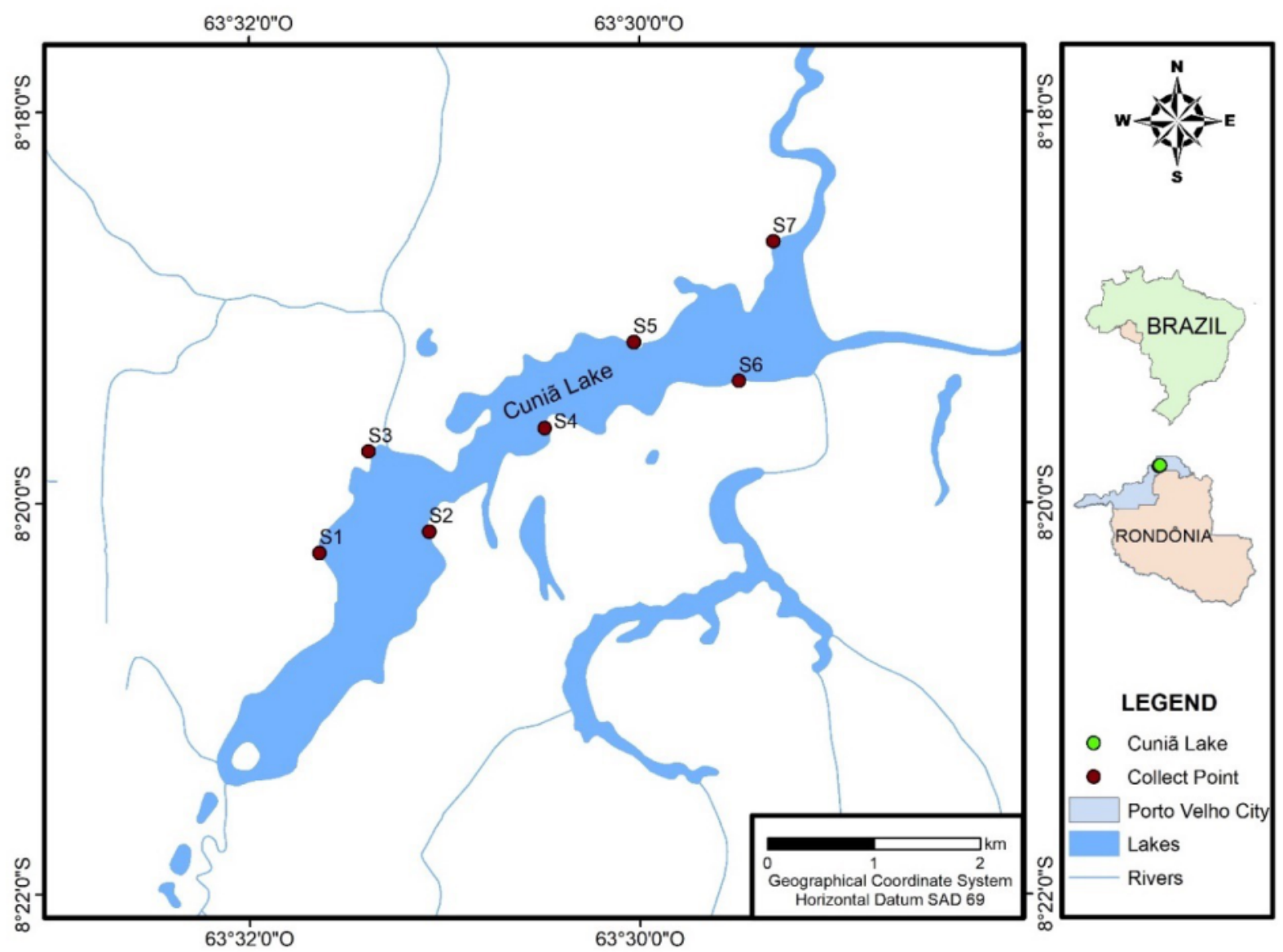

Fig. 1. Location and distribution of the seven sampling sites in Cuniã Lake, Rondônia, Brazil.

Cummins (1996); Trivinho-Strixino (2011) were used to identify macrofauna.

The environmental variables (water temperature $\left({ }^{\circ} \mathrm{C}\right)$, electric conductivity $(\mu \mathrm{S} /$ $\mathrm{cm}), \mathrm{pH}$, and dissolved oxygen $(\mathrm{mg} / \mathrm{L})$ were measured at each site in triplicate. Sediment samples were dried and calcined in muffle to measure the concentration of organic matter in sediment (Maitland, 1979). Still, this study obtained permission to data collection from the Chico Mendes Institute for Biodiversity Conservation (ICMBio), date of issue 13.05.2015 Protocol no 48977-1.

\section{Data ANALYSIS}

To investigate the potential occurrence and abundance of the different taxa recorded in the study area, a multivariate analyses technique was applied to each season. After data standardization, the relations between the taxa abundance and the limnological variables were evaluated through a Canonical Correspondence Analysis (CCA). Subsequently, a species indicator analysis was applied to evaluate the most significant taxon among all samples for each season, based on 999 permutations.

\section{RESULTS}

The low-water season presented the highest organic sediment concentration at sites S4 and S6, with $19.8 \%$ and $19.4 \%$, respectively, while the highest concentrations found in the high-water season were at sites S6 and S7, with $20.0 \%$ and $16.3 \%$, respectively. In addition, temperatures remained elevated at all collection sites, reaching a maximum of $30.27{ }^{\circ} \mathrm{C} \pm 0.363$. In general, most of the sample stations had low oxygen concentrations, with few differences occurring between the sites. However, the highwater season did present a small increase in water oxygenation, reaching a maximum value of $5.25 \mathrm{mg} / \mathrm{L} \pm 0.131$ in S5. The electrical conductivity presented the highest value during the low waters $(41.33 \mu \mathrm{S} / \mathrm{cm} \pm 0.577)$ at site $\mathrm{S} 6$, and the lowest value was $10 \mu \mathrm{S} / \mathrm{cm}$ at sites S1 and S2. On the other hand, in high waters, the highest value was $69.67 \mu \mathrm{S} / \mathrm{cm} \pm 1.155$ at site $\mathrm{S} 7$ and the lowest was found at site $\mathrm{S} 2$ with $25 \mu \mathrm{S} / \mathrm{cm} \pm$ 1.732. The $\mathrm{pH}$ values found in Cuniã Lake 
presented acidic characteristics, evidencing little variation between the seasons (Tab. 1).

Regarding the fauna data, the identification of the collected specimens revealed a total of 1009 aquatic macroinvertebrates, distributed into 28 taxa. Among the most abundant groups collected, Tenagobia (Bergroth, 1899) (Hemiptera: Corixidae), the Ostracoda class (Latreille, 1802) (Crustacea) and the genus Asheum (Sublette, 1964) (Diptera: Chironomidae) (Tab. 2). The low-water season obtained the greatest abundance, with 685 organisms collected, however, with a lower richnesss (16 taxa). In comparison, in the period of high-waters we recorded 324 organisms, distributedd in 26 taxa.

Fig. 2 shows the CCA ordination for the four significant abiotic variables $(p<0.05)$, and the representative taxa of aquatic macroinvertebrates distributed into the seven sampling sites at Cuniã Lake. The first two axes explained $64.39 \%$ of the data variability. Axis 1 explained $37.0 \%$, correlating negatively with the dissolved oxygen variable and positively with electrical conductivity, $\mathrm{pH}$, and organic matter. Axis 2, on the other hand, contributed $27.3 \%$ of data variability, and was positively correlated to dissolved oxygen. Negatively, axis 2 only correlated to organic matter. A total of $48.2 \%$ of the taxa distribution was explained by the environmental variables. Axis 1 spatially grouped taxa with higher values of electrical conductivity and organic matter. Thus, it separated more tolerant taxa from regions with higher levels of organic matter. Axis 2 shows the species richness gradient of the clustered taxa found in regions with good oxygenation and better environmental quality.

The values recorded in the indicator species index for the dry and wet season at Lake Cuniã are summarized in Tab. 3. The values identified for the entire study period show that the most significant indicator taxa were the genera Campsurus (Ephemeroptera: Polymitarcydae) and Tenagobia (Hemiptera: Corixidae). In periods of floods, the Hirudinea stand out, while in the dry period, the most

Tab. 1. Mean and standard deviation of environmental variables measured in the dry season (low waters) in August 2015, and during the rainy season (high waters) in January, 2016 in Cuniã Lake, Rondônia, Brazil. W.T.: Water temperature $\left({ }^{\circ} \mathrm{C}\right)$; E.C: electrical conductivity $(\mu \mathrm{S} / \mathrm{cm})$; DO: Dissolved oxygen (mg/L) and $\mathrm{pH}$; O.M: Organic matter (\%).

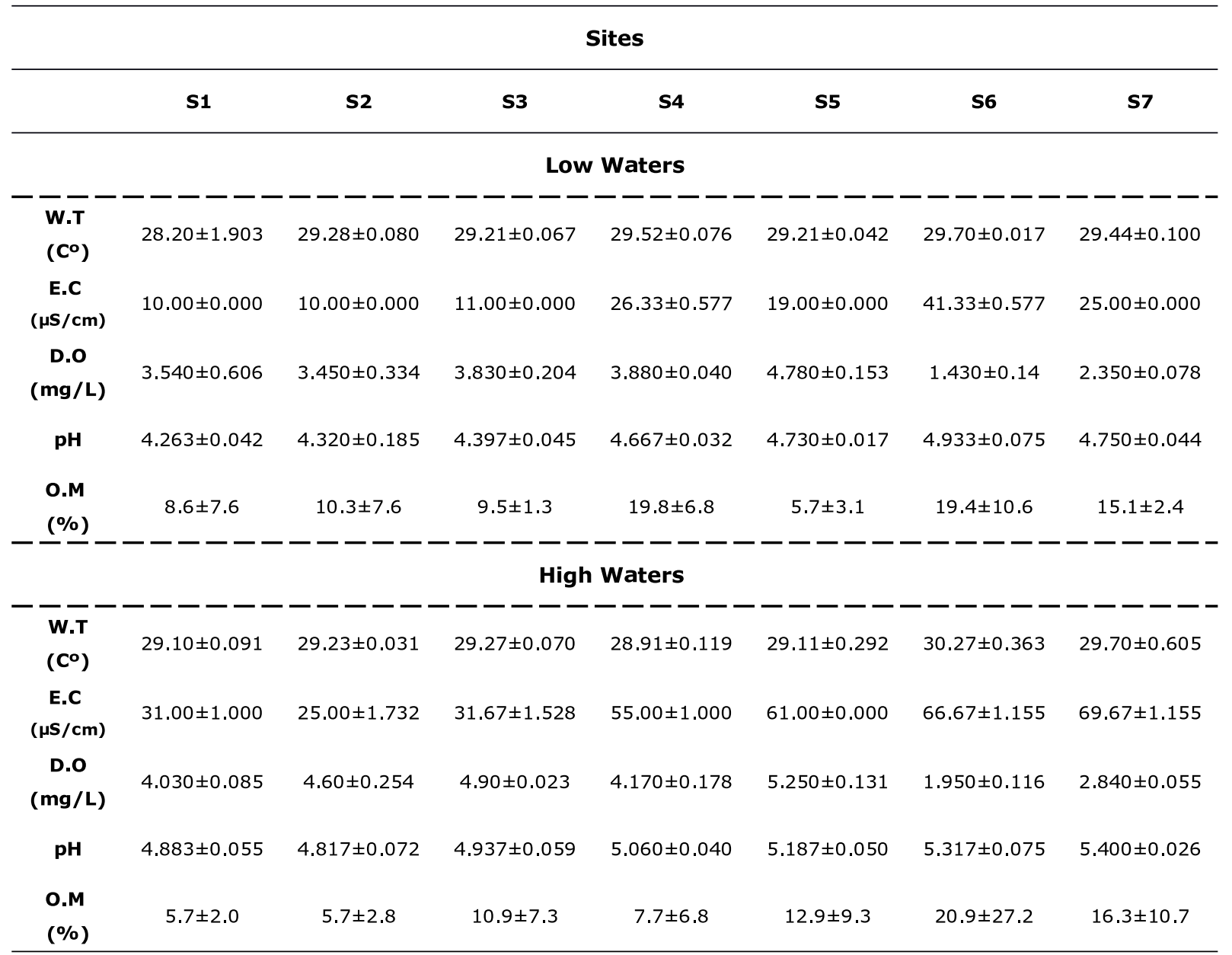


Tab. 2. Abundance of aquatic macroinvertebrates collected in the High Water (HW) and Low Water (LW) periods at the seven sites of Cuniã Lake, located in the Brazilian Amazon, Rondônia, Brazil.

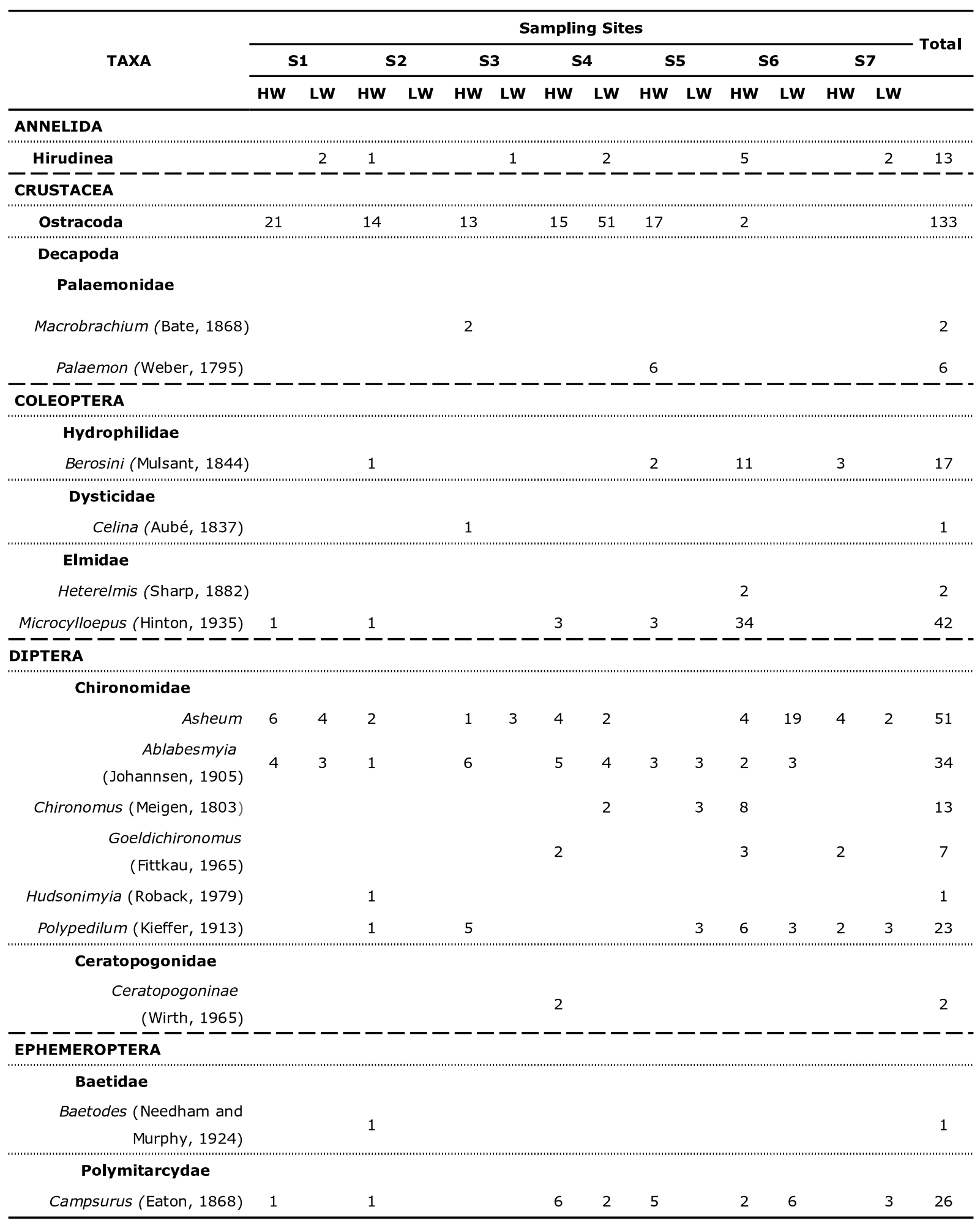


Tab. 2. Continuation

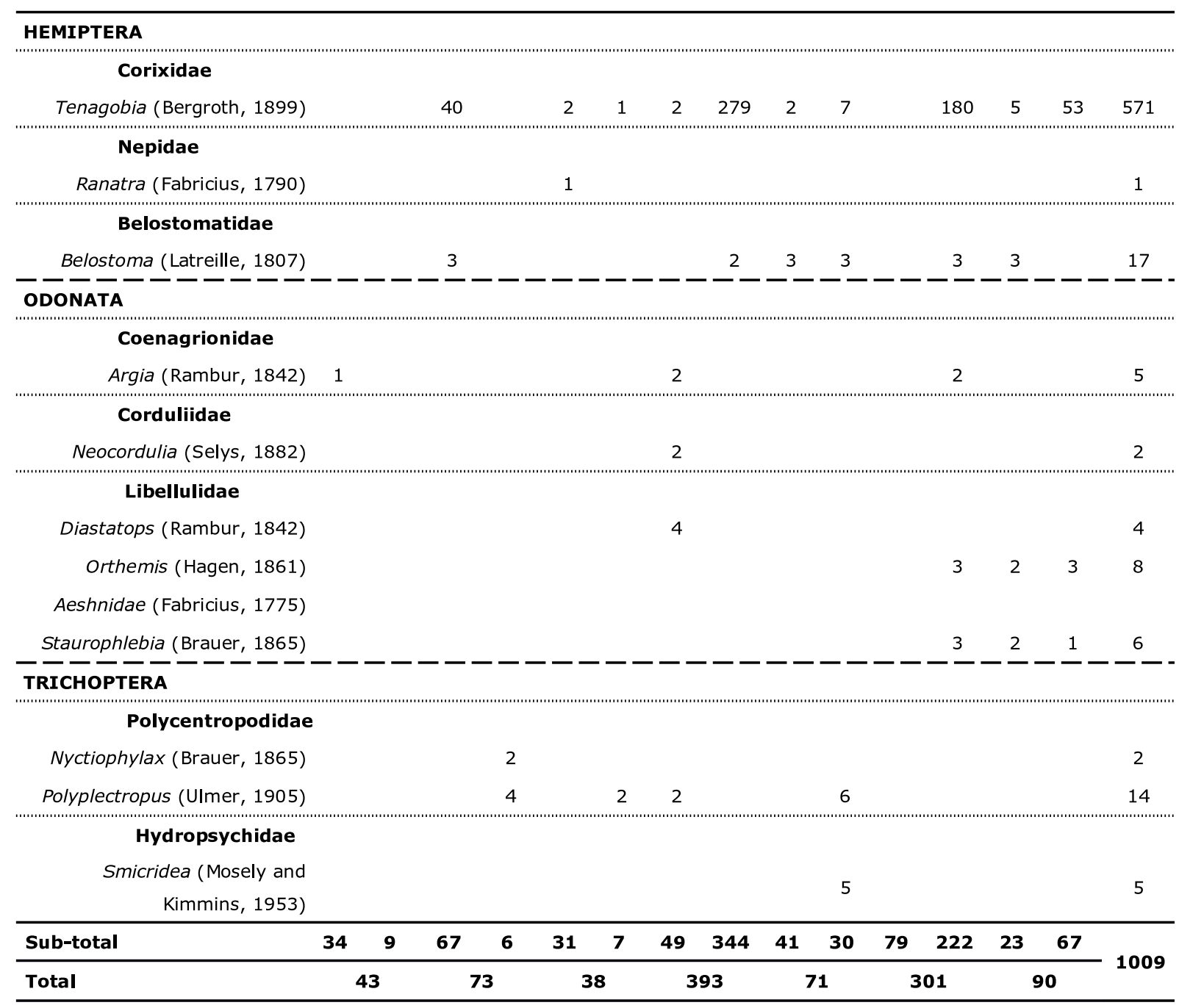

significan $t$ taxa were the representatives of the Chironomidae family (Asheum and Chironomus) (Tab. 3).

\section{Discussion}

\section{Limnological Variables}

In relation to the organic matter, some points obtained concentrations higher than $10 \%$, which characterizes them, according to Esteves (2011) as organic sediments. Still, according to the author lakes of floodplain areas usually have high concentrations, because they invade the forest and receive great contribution of matter. At the same time, this accumulation of organic matter has a rapid cycling in tropical lakes, mainly due to the high temperatures (generally above 20 ${ }^{\circ} \mathrm{C}$ ). This fact may indicate that some sites obtained values less than $10 \%$ of organic material.

High water temperature values are commonly found in these environments. Thus, Ber- nardii et al. (2009) found similar results in Amazonian lakes, always above $25{ }^{\circ} \mathrm{C}$, with maximums of $29.5{ }^{\circ} \mathrm{C}$ in both seasons and without great variations between the periods measured. Likewise, Callisto \& Esteves (1998), Almeida \& Melo (2009) and Aprile \& Darwich (2009) recorded average temperatures between $27.0^{\circ} \mathrm{C}$ and $30.3^{\circ} \mathrm{C}$ in many lakes in the Amazon region.

The dissolved oxygen measurements also presented characteristics typical of Amazonian lakes. The high temperatures, as observed in Cuniã Lake (between 28 and 29 $\left.{ }^{\circ} \mathrm{C}\right)$, decreased the solubility of oxygen in water (Esteves \& Furtado, 2011). In addition, organic matter is also related to concentration of oxygen dissolved in the lake, since the decomposition of this material changes the available dissolved oxygen (Esteves \& Furtado 2011).

In other studies, carried out in the Amazon, the values found for dissolved 
Tab. 3. Analysis of indicator species for Cuniã Lake, Rondônia, Brazil. IndVal values are the indicator values for the species in parts per unit, whereas the $p$-values are the significance values of each species based on 999 permutations. Significant values are highlighted with an asterisk $(*)$.

\begin{tabular}{|c|c|c|c|c|c|c|}
\hline \multirow{2}{*}{ Taxon } & \multicolumn{2}{|c|}{ All samples } & \multicolumn{2}{|c|}{ Low-water } & \multicolumn{2}{|c|}{ High-water } \\
\hline & Indval & p-value & Indval & p-value & Indval & p-value \\
\hline Asheum & 0.432 & 0.697 & 0.300 & 0.970 & 0.826 & $0.027 *$ \\
\hline Ablabesmyia & 0.291 & 0.823 & 0.461 & 0.233 & 0.466 & 0.416 \\
\hline Argia & 0.666 & 0.334 & 0.857 & 0.181 & 1.000 & 0.260 \\
\hline Belostoma & 0.450 & 0.763 & 0.545 & 0.624 & 0.545 & 0.529 \\
\hline Berosini & 0.305 & 0.763 & 0.620 & 0.507 & - & - \\
\hline Baetodes & 1.000 & 0.440 & 0.5000 & 0.566 & - & - \\
\hline Campsurus & 0.571 & $0.011 *$ & 0.631 & 0.159 & 0.750 & 0.222 \\
\hline Celina & 1.000 & 0.378 & 0.333 & 1.000 & - & - \\
\hline Ceratopogoninae & 0.500 & 1.000 & 1.000 & 0.260 & - & - \\
\hline Chironomus & 0.769 & 0.080 & 0.500 & 0.577 & 1.000 & $0.034 *$ \\
\hline Goeldichironomus & 0.714 & 0.078 & 0.363 & 0.953 & - & - \\
\hline Diastatops & 0.500 & 1.000 & 1.000 & 0.285 & - & - \\
\hline Heterelmis & 0.500 & 1.000 & 0.500 & 0.598 & - & - \\
\hline Hudsonimyia & 1.000 & 0.430 & 0.500 & 0.585 & - & - \\
\hline Hirudinea & 0.411 & 0.659 & 1.000 & $0.044 *$ & 0.625 & 0.110 \\
\hline Macrobrachium & 1.00 & 0.442 & 0.333 & 1.000 & - & - \\
\hline Microcylloepus & 0.840 & 0.469 & 0.801 & 0.535 & - & - \\
\hline Neocordulia & 0.500 & 1.000 & 1.000 & 0.304 & - & - \\
\hline Nyctiophylax & 1.000 & 0.407 & - & - & 1.000 & 0.315 \\
\hline Orthemis & 0.312 & 1.000 & 1.000 & 0.288 & 0.750 & 0.311 \\
\hline Ostracoda & 0.375 & 0.899 & 0.425 & 0.232 & 0.500 & 0.576 \\
\hline Palaemon & 0.500 & 1.000 & 0.333 & 1.000 & - & - \\
\hline Polyplectropus & 0.400 & 0.877 & 1.000 & 0.286 & 0.521 & 0.578 \\
\hline Polypedilum & 0.344 & 0.803 & 0.488 & 0.708 & 0.545 & 0.645 \\
\hline Ranatra & 1.000 & 0.467 & 0.333 & 1.000 & - & - \\
\hline Smicridea & 0.500 & 1.000 & - & - & 0.500 & 0.558 \\
\hline Staurophlebia & 0.250 & 1.000 & 1.000 & 0.288 & 0.900 & 0.201 \\
\hline Tenagobia & 0.750 & $0.025^{*}$ & 0.352 & 0.966 & 0.527 & 0.760 \\
\hline
\end{tabular}

oxygen concentration were equivalent to those obtained in this study, i.e., according to Almeida \& Melo (2009), the concentration of dissolved oxygen presented a mean like those found in this study. Similarly, Bernardi et al. (2009) reported values between 3.6 and 5.5 $\mathrm{mg} / \mathrm{L}$ at different sampling sites. These results support the data obtained by Carvalho et al. (2001), which states that tropical lakes in floodplain areas usually presents low values of dissolved oxygen in water, especially in the lower layers.

Another important variable in aquatic ecosystems is electrical conductivity, since it can provide important information about what occurs in the drainage basin. Therefore, this data is fundamental for analyzing the trophic state of water, especially in environments with anthropic influence (Esteves et al., 2011a). In the highwater season this variable presented values of $66.67 \mu \mathrm{S} / \mathrm{cm}$ in $\mathrm{S} 6$ and S7, and lower values in $\mathrm{S} 2,25 \mu \mathrm{S} / \mathrm{cm}$. The local anthropic influence in Cuniã Lake can be considered low, since few families are distributed around the lake, which may have reflected in the low electrical conductivity average. This variation between the values found in the different seasons was described by Bernardi et al. (2009), who associated this variability to the transport and 
leaching of organic substances of Madeira River in high-water season.

In addition, Esteves (2011) estated that electrical conductivity in the low-water period generally presents lower values when compared to the high-water period. This goes against the study of Almeida \& Melo (2009), conducted at a floodplain lake in the city of Manaus (AM), reaching averages between 20 and $30 \mu \mathrm{S} / \mathrm{cm}$. The same was observed in the study of Callisto \& Esteves (1998) with values between 10 and $33 \mu \mathrm{S} /$ $\mathrm{cm}$. Furthermore, Esteves (2011) identified that the electrical conductivity in the Amazon region is also influenced by geological factors.

In relation to the low $\mathrm{pH}$ values variation, Esteves \& Marinho (2011) and Vieira et al. (2018) affirm that the Amazonian lakes present $\mathrm{pH}$ values around 5, due to acidic soils, as well as to dark waters, rich in humic substances. In addition, the studies conducted by Callisto \& Esteves (1998) and Bozelli (2000) found values very close to those of Cuniã Lake, with a minimum of 4.1 and a maximum of $4.8,5.5$ and 6.2 in Cuniã and Batata Lakes, respectively (Porto Trombetas, PA, Brazil).

\section{Aquatic macrofauna}

The most representative taxa, with $57 \%$ of the collected organisms, were the Heteroptera suborder of the genus Tenagobia, which are composed of small aquatic insects that preferentially inhabit lentic environments with low depth and presence of vegetation (Nieser \& Melo, 1997; Roldán, 1988; DiasSilva et al., 2010). Moreover, these organisms are commonly found in many neotropical countries and states in Brazil (Morrone et al., 2004).

Additionally, according to the CCA (Fig. 2 ), this genus has no direct relation to any of the physical and chemical variables, demonstrating that it can be widely tolerant to many different environmental conditions. Thus, $\mathrm{Te}-$ nagobia was one of the most significant species in this study, as shown by the IndVal analysis (Tab. 3), collected abundantly in both seasons and present at practically all sampling sites, becoming one of the indicator species in Cuniã Lake. In addition, the Naucoridae family, of which the genus Tenagobia is inserted, has already been found both in

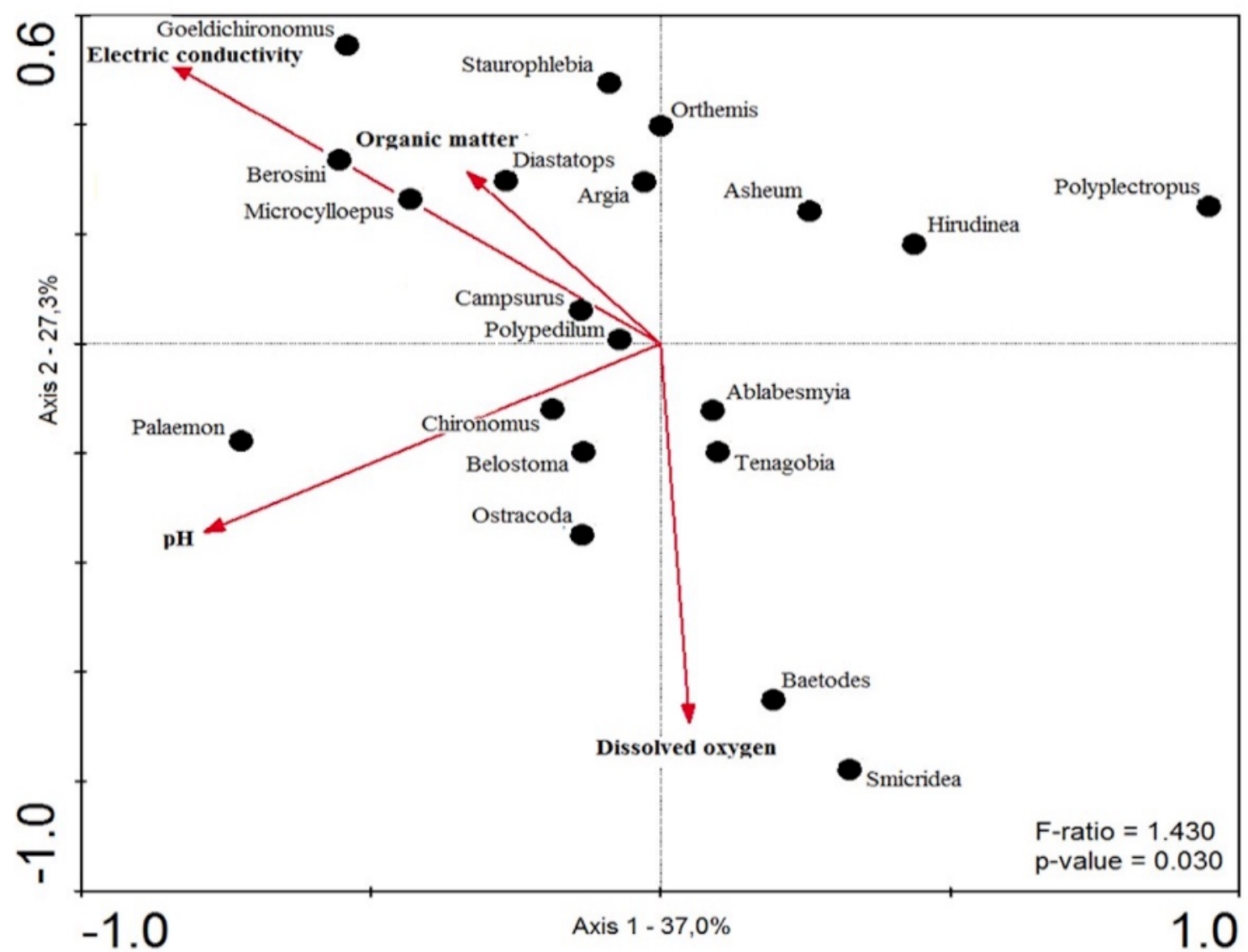

Fig. 2. Canonical Correspondence Analysis (CCA) diagram based on the abundance data of aquatic macroinvertebrate collected at high- and low-water stations at seven sampling sites at Cuniã Lake Rondônia, Brazil. 
environments with little or no human impact and in more polluted environments, suggesting that this group presents high plasticity for many environmental conditions (Souza et al., 2006; Couceiro et al., 2007).

The second most representative group, with $13 \%$ of the total collected specimens, was the Ostracoda class, composed of small bivalve crustaceans (Pieri et al., 2007; Higuti \& Martens, 2016) that can reach high population density in the neotropical aquatic macrofauna, mainly associated with aquatic vegetation (Higuti et al., 2009). The great amount of vegetal biomass in Cuniã Lake can be an important factor that influenced the success of colonization of this group in the studied ecosystem. According to Mormul et al. (2010), these organisms use the vegetation for protection against predators and for spawning. Furthermore, as Esteves (2011) indicates, they play an important role in the nutrients cycle and the food chain, being a source of resources for other invertebrates and fish. Also, in CCA analysis, the Ostracoda class also exhibited no correlation with the measured variables.

Another significant taxa in this study, with $13 \%$ of the total organisms collected, were the Chironomidae, represented by the genera Asheum, Ablabesmyia, Ceratopogoninae, Chironomus, Goeldichironomus, Hudsonimyias, and Polypedilum. According to Roque et al. (2003) and Brito Júnior (2005), these organisms are commonly found in generally eutrophic places with higher amounts of organic matter (Cleto-Filho \& Walker, 2001). However, many authors have already evidenced this family in the Amazonian ecosystems (Callisto \& Esteves, 1998; Lopes et al., 2008; Fidelis et al., 2008).

Chironomidae are related with aquatic macrophytes and roots, and easily adapt themselves to inhabit many different environments (Hamada et al., 2014; Corbi \& TrivinhoStrixino, 2017). Moreover, in studies carried out in Igarapés, located city the of Manaus (AM), Couceiro et al. (2007) classified these organisms as tolerant even to environments impacted by deforestation and organic discharge, evidencing that the natural conditions found in Cuniã lake, such as low oxygenation and organic enrichment, may favor the occurrence of this group.

However, as the CCA shows (Fig. 2) that many of the organisms belonging to the Chironomidae family were close to the center of the axis, which means that these specimens were not strongly influenced by any of the environmental variables measured. However, the genera Asheum and Chironomus were the most significant taxa, as shown by the IndVal analysis (Tab. 3) in the low water season, possibly because of the organic matter concentration and low oxygenation at site S6, in which these genera occurred with greater abundance. This fact can be explained by the high abundance and diversity of the group, being composed by both sensitive and tolerant species (Nicacio \& Juen, 2015), found in practically all aquatic ecosystems, surviving in the most varied limnological conditions (Esteves, 2011b).

Studies about Chironomidae diversity in the Amazon region are still scarce (Couceiro et al., 2010; Fidelis et al., 2008; Fusari et al., 2009). However, in recent years, researchers have been trying to understand and record the occurrence and ecological relationships of this family in the Amazon region (Soares \& Vieira, 2012).

All the other organisms collected in Cuniã Lake composed $17 \%$ of the total collected organisms. It is worth mentioning that in the canonical correlation analysis, some taxa had direct correlation with specific variables such as: Baetodes, related to dissolved oxygen; Diastatops and Microcylloepus, associated with organic matter; and Palaemon, with $\mathrm{pH}$. The IndVal analysis also indicated that Hirudinea were indicators of the high-water season, which were more commonly present at site S6. These organisms are very common in freshwater environments and are found in many ecosystems (Esteves et al., 2011b).

In addition, this study also reported the occurrence of relatively more sensitive taxa belonging to the order Ephemeroptera, of which the main representatives were the Baetodes and Campsurus. The genus Campsurus was one of the indicator species of Cuniã Lake, by the IndVal analysis, and was present in many sites, including S6, characterized by the high concentration of organic matter. Callisto \& Esteves (1996) also found this genus in Amazonian lakes related to sites that exhibited high concentrations of organic matter, evidencing the food habit of the genus, which is mainly composed of bacteria and organic debris adhered to sediment particles.

The Trichoptera order, also related to less impacted environments, was represented by the genus Nyctiophylax, Polyplectropus and Smicridea. Thus, the macrofauna structure found in Cuniã Lake was composed of many taxa that occur in forested and non-impacted Amazonian environments (Cleto-Filho \& Walker, 2001; Esteves, 2011), as well as tolerant taxa related mainly to organically enriched environments.

Based on the results, this study shows that the Cuniã Lake presents favorable environmental conditions from the physical and chemical perspective, considering the patterns for lakes of floodplain areas of Neotropical regions. Also, the community of aquatic macroinvertebrates presented organisms typically found in environments rich in organic matter. In addition, these results 
contribute to increase the knowledge of the aquatic macrofauna in the Brazilian Amazon and to reduce the gaps in the neotropical biodiversity data.

\section{ACKNOWLedgements}

The authors thank the Coordenação de Aperfeiçoamento de Pessoal de Nível Superior (CAPES) for financial support and Instituto Chico Mendes de Conservação da Biodiversidade (ICMBio) for collection assistance, especially to the coordinator of the Reserve, Cristiano Andrey Souza do Vale.

\section{References}

Alves, R. G. \& G. R. Gorni. 2007. Naididae species (Oligochaeta) associated with submersed aquatic macrophytes in two reservoirs (São Paulo, Brazil). Acta Limnol. Bras. 19(4): 407-413.

Almeida, F. F. \& S. Melo. 2009. Considerações limnológicas sobre um lago da planície de inundação amazônica (Lago Catalão-Estado do Amazonas, Brasil). Acta Scient. Biol. Sci. 31(4): 387-395.

Aprile, F. M. \& A. J. Darwich. 2009. Regime térmico e a dinâmica do oxigênio em um lago meromítico de águas pretas da região amazônica. Braz. J. of Aquatic Sci. and Tech. 13(1): 37-43.

Aprile, F. \& A. J. Darwich. 2013. Nutrients and water-forest interactions in an Amazon floodplain lake: an ecological approach. Acta Limno. Bras. 25(2): 169-182.

Cleto-Filho, S. E. N. \& I. Walker 2001. Efeitos da ocupação urbana sobre a macrofauna de invertebrados aquáticos de um igarapé da cidade de Manaus/AM-Amazônia Central. Acta Amaz. 31(1): 69-89.

Callisto, M. \& F. A. Esteves. 1998. Caracterização funcional dos macroinvertebrados bentônicos em quatro ecossistemas lóticos sob influência das atividades de uma mineração de bauxita na Amazônia central (Brasil). Oecol. Bras. 5(1): 223-234.

Callisto, M. \& F. A. Esteves. 1996. Macroinvertebrados bentônicos em dois lagos amazônicos: Lago Batata (um ecossistema impactado por rejeito de bauxita) e Lago Mussurá (Brasil). Acta Limn. Bras. 8(1): 137-147.
Couceiro, S. R., N. Hamada, S. L. Luz, B. R. Forsberg \& T. P. Pimentel. 2007. Deforestation and sewage effects on aquatic macroinvertebrates in urban streams in Manaus, Amazonas, Brazil. Hydrobiologia. 575(1): 271-284.

Corbi, J. J. \& S. Trivinho-Strixino. 2017. Chironomid species are sensitive to sugarcane cultivation. Hydrobiologia. 785(1): 91-99.

Esteves, F. D. A. 2011. Fundamentos de limnologia, 3. ed. Rio de Janeiro: Interciência.

Esteves, F. A. \& A. S. Furtado. 2011. Oxigênio dissolvido. pp. 167-190. In: Esteves, F. A. (Org.). Fundamentos de limnologia. 3. ed. Rio de Janeiro: Interciência.

Esteves, F. A. \& C. C Marinho. 2011. Carbono inorgânico.pp. 193-207. In: Esteves, F. A. (Org.). Fundamentos de limnologia, 3. ed. Rio de Janeiro: Interciência, 2011. 790 p.

Esteves, F. A., M. P. Figueiredo-Barros \& M. M. Petrúcio. 2011a. Principais cátions e Ânions. pp. 299-319. In: Esteves, F. A. (Org.). Fundamentos de limnologia, 3. ed. Rio de Janeiro: Interciência.

Esteves, F. A., J. J. F. Leal, \& M. Callisto. 2011b. Comunidade Bentônica. pp. 581603. In: Esteves, F. A. (Org.). Fundamentos de limnologia, 3. ed. Rio de Janeiro: Interciência.

Fidelis, L., J. L. Nessimian, \& N. Hamada. 2008. Distribuição espacial de insetos aquáticos em igarapés de pequena ordem na Amazônia Central. Acta Amaz. 38(1): 127-134.

Hamada, N., J. L. Nessimian \& R. B. Querino. 2014. Insetos aquáticos na Amazônia brasileira: taxonomia, biologia e ecologia. Manaus: Editora do INPA. 724 p.

Hortal, J., F. de Bello, J. A. F. Diniz-Filho, T. M. Lewinsohn, J. M. Lobo \& Ladle, R. J. 2015. Seven shortfalls that beset large-scale knowledge of biodiversity. Annual Rev. of Eco., Evol., and System. 46. 523-549. 
Higuti, J. \& K. Martens. 2016. Invasive South American floating plants are a successful substrate for native Central African pleuston. Biol. Invasions. 18(4): 1191-1201.

Junk, W. J. 1997. General aspects of floodplain ecology with special reference to Amazonian floodplains. pp. 3-20. In: Junk, W. J. (Ed.). The Central Amazon Floodplain. Springer, Berlin, Heidelberg.

Lopes, M. J. N., M. D. S. R. da Silva, R. T. de Moreira Sampaio \& E. L. L. Belmont 2008. Avaliação preliminar da qualidade da água de bacias hidrográficas de Manaus utilizando macroinvertebrados como bioindicadores. SaBios-Revista de Saúde e Biologia. 3(2): 1-9.

Maitland, P. S. 1979. The distribution of zoobenthos and sediments in Loch Leven, Kinross, Scotland. Archiv fur Hydrobiologie. 85: 98-125.

Magurran, A. E. 2011. Medindo a diversidade biológica. Editora UFPR: Paraná. 262 p.

Morrone, J. J., S. A Mazzucconi \& A. O. Bachmann. 2004. Distributional patterns of chacoan water bugs (Heteroptera: Belostomatidae, Corixidae, Micronectidae and Gerridae). Hydrobiologia. 523(1-3): 159-173.

Monteiro, C. D. S., L. Juen, \& N. Hamada. 2005. Analysis of urban impacts on aquatic habitats in the central Amazon basin: adult odonates as bioindicators of environmental quality. Ecol. Indic. 48. 303-311.

Merritt, R. W. \& K. W. Cummins. (Eds.). 1996. An introduction to the aquatic insects of North America. Kendall Hunt. $862 \mathrm{p}$.

Mormul, R. P., S. M. Thomaz, J. Higuti. \& K. Martens. 2010. Ostracod (Crustacea) colonization of a native and a non-native macrophyte species of Hydrocharitaceae in the Upper Paraná floodplain (Brazil): an experimental evaluation. Hydrobiologia. 644(1): 185-193.

Nessimian, J. L., L. F. M. Dorvillé, A. M. Sanseverino \& D. F. Baptista. 1998. Relation between flood pulse and functional composition of the macroinvertebrate benthic fauna in the lower Rio Negro, Amazonas, Brazil. Amazoniana. 15(1): 35-50.
Nicacio, G. \& L. Juen. 2015. Chironomids as indicators in freshwater ecosystems: an assessment of the literature. Insect Conserv. and Divers. 8(5): 393-403.

Nieser, N. \& A. L. D. Melo. 1997. Heterópterosaquáticos de Minas Gerais. Editora Ufmg. $177 \mathrm{p}$.

Roldán, G. 1998. Guía para elestudio de los macroinvertebrados acuáticos del Departamento de Antioquia. Medellín: Universidad de Antioquia, Fondo FEN. 226 p.

Souza A. A., M. A. L. \& M. E. G. J. Vianna 2006. Heterópteros aquáticos oriundos do Município de Mariana, MG. Neotrop. Entomol. 35(6): 803-810.

Soares Vieira, L. J., G. C. Rosin, A. Michiyo Takeda, M. R. Marques Lopes \& D. Silva de Sousa. 2012. Studies in SouthOccidental Amazon: contribution to the knowledge of Brazilian Chironomidae (Insecta: Diptera). Acta Scient. Bio. Sci. 34(2): 149-153.

Trivinho-Strixino, S. 2011. Chironomidae (Insecta, Diptera, Nematocera) from São Paulo State, Southeast of Brazil. Biota Neotrop. 11: 675-684.

Uherek, C. B. \& F. B. Pinto Gouveia. 2014. Biological monitoring using macroinvertebrates as bioindicators of water quality of Maroaga Stream in the Maroaga Cave System, Presidente Figueiredo, Amazon, Brazil. Intern. J. of Ecol. 2014: 1-7.

Van den Berg, M. S., H. Coops, R. Noordhuis, J. Van Schie \& J. Simons. 1997. Macroinvertebrate communities in relation to submerged vegetation in two Charadominated lakes. Hydrobiologia. 342: 143150.

Vieira, M., J. V. E. Bernardi, J. G. Dórea, B. C. P. Rocha, R. Ribeiro \& L. F. Zara. 2018. Distribution and availability of mercury and methylmercury in different waters from the Rio Madeira Basin, Amazon. Environ. Pollut. 235: 771-779.

Wetzel, R. G. 2001. Limnology: lake and river ecosystems Gulf Professional Publishing. $841 \mathrm{p}$.

Recebido em 18.III.19 Aceito em 30.VII.19 